\title{
Radiocarbon dates for coastal midden sites at Long Point in the Coorong, South Australia
}

\author{
Claire St George ${ }^{1,2}$, Lynley A. Wallis ${ }^{1,2}$, Benjamin Keys ${ }^{1}$, Christopher Wilson ${ }^{1,3}$, Duncan \\ Wright $^{4}$, Stewart Fallon ${ }^{5}$, Major (Moogie) Sumner ${ }^{6}$, Steve Hemming ${ }^{7,3}$ and the Ngarrindjeri \\ Heritage Committee ${ }^{8}$
}

\begin{abstract}
This paper presents 29 radiocarbon dates from eight surface concentrations of shell and 10 test-pits across four shell middens at Long Point in the Coorong, South Australia. Results indicate that occupation of these sites was confined to the late Holocene period, post- 2500 cal. BP. With the exception of one midden, which appears not to have been used after 500-300 cal. BP, all other sites suggest continued use until the recent past. This pattern fits with a proposed period of population expansion and intensification of resource use in the Coorong, along with more general changes known to have occurred in parts of coastal Australia during the mid- to late Holocene.
\end{abstract}

\section{Introduction}

The Murray River, Coorong and Lower Lakes are the traditional ruwe (lands and waters) of the Ngarrindjeri people (Ngarrindjeri Tendi et al. 2007). Eighteenth and nineteenth century ethnographers recorded aspects of Ngarrindjeri culture and lifestyle, highlighting a successful and sustainable culture in which people utilised the open sea, as well as the more protected lagoons, bays and river mouths, in addition to terrestrial resources in the hinterland (e.g. Angas 1847a, 1847b; Beveridge 1882; Campbell 1934, 1939, 1947; Taplin 1874). This led to the suggestion that, prior to European arrival, this region was one of the most densely populated areas in Australia (Tindale 1974).

Ascertaining causes for changes evident in the late Holocene archaeological record has long been the subject of debate in Australia (Bowdler 1981; Flood 1999; Hiscock 1994, 2006; Lourandos 1980, 1983, 1985, 1988; Mulvaney 1969), with intensification proposed as one explanation (Lourandos 1980, 1983). Other suggestions offered include both internal factors, such as population increase or changes in social organisation (e.g. Barker 2004; David 2002; Hughes and Lampert 1982), and external factors, such as environmental change (e.g. Beaton 1985; Rowland 1983, 1989, 1999). Prior to these discussions, Luebbers

\footnotetext{
1 Department of Archaeology, Flinders University, GPO Box 2100, Adelaide SA 5001, Australia

<claire.stgeorge@wallisheritageconsulting.com.au>

${ }^{2}$ Wallis Heritage Consulting, 1B Swan Street, Brighton SA 5048,

Australia <lynley.wallis@wallisheritageconsulting.com.au>

${ }^{3}$ Yunggorendi First Nations Centre for Higher Education and Research, Flinders University, GPO Box 2100, Adelaide SA 5001, Australia $<$ christopher.wilson@flinders.edu.au>

${ }^{4}$ Duncan Wright, Place, Evolution and Rock Art Heritage Unit, Humanities, Gold Coast Campus, Griffith University Old 4222, Australia <d.wright@griffith.edu.au>

${ }^{5}$ Research School of Earth Sciences, The Australian National University, Canberra ACT 0200, Australia <stewart.fallon@anu.edu.au>

${ }^{6}$ Dapung Talkinjeri Aboriginal Corporation, c/- PO Box 126, Meningie SA 5264, Australia

7 Department of English, Creative Writing and Australian Studies, Flinders University, GPO Box 2100, Adelaide SA 5001, Australia <steve.hemming@flinders.edu.au>

${ }^{8}$ PO Box 126, Meningie SA 5264, Australia
}

$(1978,1981,1982)$ had documented an array of archaeological changes in the Coorong in the post-2000 BP period and, based on observed economic changes, suggested four main phases of occupation:

- An early settlement phase (6000-4500 BP);

- An initial coastal settlement phase (4500-2000 BP);

- An intensive settlement phase (2000-AD 1840s); and,

- A refugee phase (AD 1840s-present).

Recent studies in the Coorong have continued to build on our understanding of Ngarrindjeri occupation and habitation, focusing on research into repatriation, gendered archaeology, skeletal analysis and heritage legislation (e.g. Baric 2006; Meara 2007; Niland 2007; Wilson 2005; Wiltshire 2005; Wiltshire and Wallis 2008); these studies generally have not included the dating of archaeological sites.

In this paper we report 29 new radiocarbon dates from eight surface concentrations of shell and 10 test-pits across four middens at the Coorong that test the validity of Luebbers' occupation model. This dating was undertaken in order to provide a robust timeline for developing a local model for late Holocene occupation in the region (cf. Ulm 2013). Details on the excavated cultural materials, and a discussion as to how these sites relate to broader occupation patterns and the intensification debate, can be found in St George (2009); manuscripts on these aspects are currently being prepared for publication.

\section{The Study Area}

The study area, known as Long Point, is located in the Coorong, a shallow saline lagoon situated landward of the Younghusband Peninsula, approximately $150 \mathrm{~km}$ southeast of Adelaide (Figure 1). Long Point stretches approximately $3 \mathrm{~km}$ along the eastern landward margin of the northern Coorong, from the shoreline up to $800 \mathrm{~m}$ inland. The landscape is predominately low-lying; the terrain in the north is dominated by low, undercut limestone platforms, while active Holocene sand dunes up to 20-40 m above mean sea level are prevalent in the southern study area. Many of these dunes have experienced extensive blowouts and are somewhat destabilised, are underlain by lithified Pleistocene dunes and bear a thin calcrete crust (Harvey 1981:4). The modern coastal barriers of Sir Richard and Younghusband Peninsulas developed ca 7000-6000 BP, after the transgressing sea reached its present level (Harvey 1981).

The three main sources of water into the Coorong are freshwater flows from the Murray River, marine incursion through the Murray Mouth and winter rainfall (Barnett 1995). The construction of barrages for irrigation and water regulation in the early 1900s caused severe degradation of the Coorong ecosystem and hydrology; increased sedimentation 
and constriction of the Murray Mouth has resulted in minimal marine inflows and there is little inflow of freshwater from the lakes (Fluin et al. 2007; Krull et al. 2009). Prior to water regulation, seasonal fluctuations in water levels supported a diverse array of vegetation and vertebrate and invertebrate fauna.

\section{Methodology}

Initiated in 2007 as a component of their broader management programme, Dapung Talkinjeri Aboriginal Corporation (DTAC) requested archaeological surveys be undertaken at Long Point. These surveys identified 21 sites, comprising 15 shell matrix sites, five historic sites and one burial (Wallis 2007a, 2007b). With permission from DTAC and Ngarrindjeri Heritage Committee (NHC), surface samples of shell from several of the recorded sites were collected and dated.

This initial survey provided the foundation for a collaborative NHC-Flinders University field-school held in 2008, during which four sites were excavated: LP4, LP9, LP11 and LP16 (Wallis and Disspain 2008). As the sites were often large and continuous, excavation trenches were not logistically feasible, and thus discrete test-pits were chosen as the means of investigating the sub-surface deposits (cf. Bowdler 1983:137, 2006:323). A total of 12 test-pits were excavated:

- Two in LP4 (Squares AA10 and AK14);

- Three in LP9 (Squares AD, AY12 and Y);

- Three in LP11 (Squares A, B and C); and,

- Four in LP16 (Squares A8, L8, A20 and L20).

In addition, one surface shell matrix site (LP8) was recorded in detail, and seven radiocarbon dates were obtained from other surface concentrations of shell (Figure 2).

\section{Excavation}

All test-pits were excavated by $5 \mathrm{~cm}$ spits (unless a stratigraphic change was encountered) until culturally sterile sediments or limestone bedrock was reached. For each spit the volume of sediment removed was recorded to the nearest $0.1 \mathrm{~kg}$, and $\mathrm{pH}$ and Munsell soil colours were assessed. Bulk sediment samples were taken from each excavation spit, and in situ shell and charcoal samples for radiocarbon dating were collected during excavation. Stratigraphic drawings and photographs were taken of each section, along with end level photographs of each spit for each excavation square. Detailed context sheets were recorded for each excavation spit, and offset plans drawn for each site.

\section{Surface Recording}

Shell scatter site LP8 was gridded using 5 x $5 \mathrm{~m}$ squares covering a total area of $30 \times 25 \mathrm{~m}$. The entire grid was subject to systematic pedestrian survey by at least five team members, with the location of each individual shell, otolith and stone artefact plotted. As large quantities of shell were present and it was not feasible, nor desirable, to collect them all, the cultural material in six $1 \times 1 \mathrm{~m}$ randomly located squares across LP8 were collected for analysis.

\section{Radiocarbon Dating}

Five shell samples and one charcoal sample collected from the surfaces of six sites surveyed in 2007 were dated that year by one of the authors (BK) (Wk-21215, Wk-21217, Wk-21218, ANU
3113, ANU 2637 and ANU 2638). Radiocarbon dating of an additional 23 in situ samples excavated in 2008 was undertaken by another author (CSG). Both the 2007 and 2008 sets of samples were prepared and analysed under the supervision of a third author (SF), at The Australian National University using the single stage accelerator mass spectrometer (Fallon et al. 2010). For the 23 excavated samples, charcoal was chosen in preference to shell in a bid to avoid uncertainties about reservoir correction factors (Ulm 2006a, 2006b), though shell had to be dated in lieu of charcoal in two sites (LP4, Square AA10, and LP11, Square B).

Charcoal was treated following standard ABA methods (Brock et al. 2010). Carbon dioxide recovered from charcoal and shell was purified and converted to graphite following Santos et al. (2004). The quoted uncertainty on the radiocarbon age is reported in Table 1, using the convention of Stuiver and Polach (1977). Conventional radiocarbon ages of both the shell and charcoal samples were calibrated to calendar years BP using CALIB ${ }^{\circledR}$ v5.0.1 software, employing the SHCal04 atmospheric curve, and the Marine04 curve for ${ }^{14} \mathrm{C}$ variations between the Northern and Southern Hemispheres (Hughen et al. 2004; McCormac et al. 2004) at a $2 \sigma$ age-range, $95.4 \%$ probability. A reservoir correction factor of $72 \pm 55$ was applied to the shell samples to account for local marine reservoir effects (Ulm 2006a).

\section{Results}

The radiocarbon dates obtained from the four excavated sites are listed in Table 1. Stratigraphic sections and plans for each of these sites are presented in the online supplementary material.

\section{Site LP4}

LP4 is a low density, shallow midden approximately $50 \mathrm{~m}$ in diameter, situated on a north-facing limestone cliff, into which two $1 \times 1 \mathrm{~m}$ test-pits were excavated (Squares AK10 and AK14). Three radiocarbon dates were obtained from this site: a general surface date (collected in 2007), and basal dates from the two test-pits. The surface shell sample returned an age estimate of 491-271 cal. BP. The basal date in Square AK14, located near the edge of the midden, returned an age estimate of $321 \mathrm{cal}$. BPmodern, while in Square AA10 shell associated with the lowest cultural material produced an age estimate of $947-673 \mathrm{cal}$. BP.

\section{Site $L P 9$}

LP9 is an extensive shell midden that stretches ca $500 \mathrm{~m}$ in a $30 \mathrm{~m}$ wide band, approximately $30 \mathrm{~m}$ from the current lagoon shoreline. Three $1 \times 1 \mathrm{~m}$ test-pits (Squares AY12, Y and AD) were excavated at LP9, from which eight radiocarbon dates were obtained. A surface sample of Donax deltoides collected during 2007, and thus unrelated to a specific test-pit, returned an age estimate of 1501-1227 cal. BP.

The basal age for Square AD was 2121-1897 cal. BP, while a second sample from $20-30 \mathrm{~cm}$ below surface (bs) - where cultural material was densest-returned an age estimate of 1816-1569 cal. BP. A sample from the uppermost $5 \mathrm{~cm}$ of Square $\mathrm{AD}$ returned a modern date. The basal age for Square AY12 was $1822-1570 \mathrm{cal}$. BP and a sample obtained $5-10 \mathrm{~cm}$ bs returned an age of 439 cal. BP-modern. A basal sample from Square Y returned an age estimate of 2455-2134 cal. BP, and another from $25-30 \mathrm{~cm}$ bs (again where cultural material was densest), returned an age estimate of 2306-1951 cal. BP. 


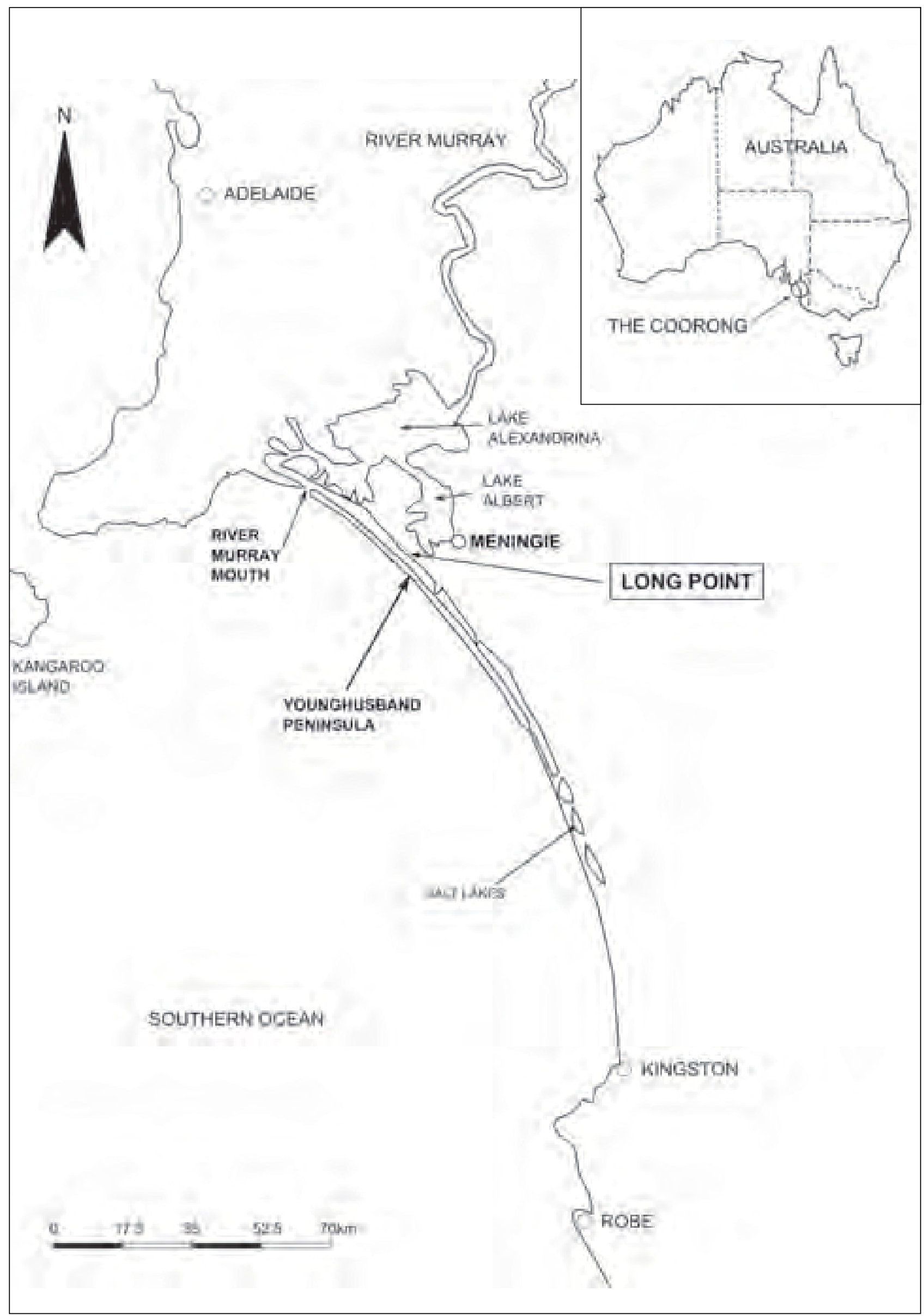

Figure 1 Location of Long Point, Coorong, South Australia. 


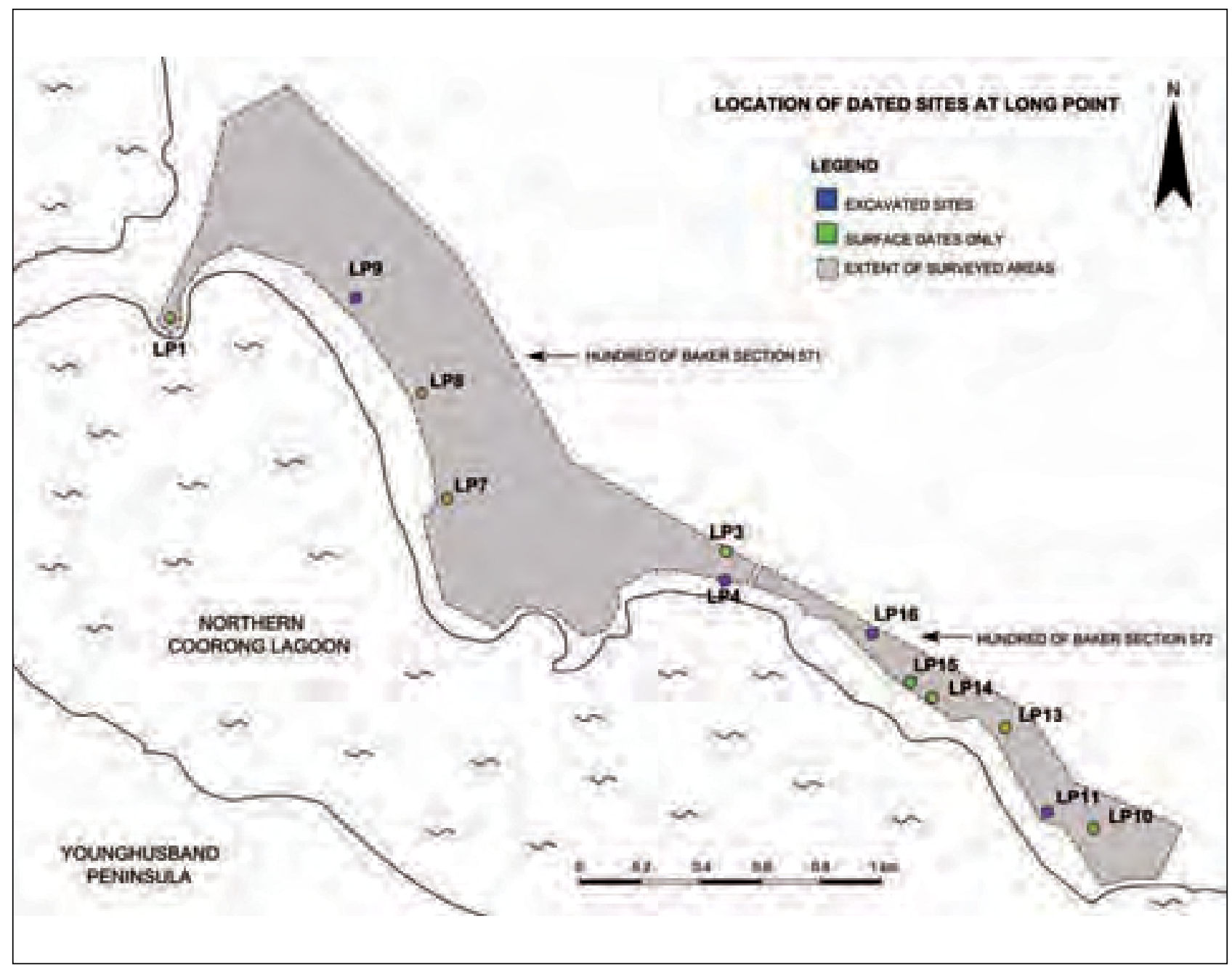

Figure 2 Location of dated sites at Long Point.

\begin{tabular}{|l|l|l|l|r|c|c|c|c|}
\hline $\begin{array}{l}\text { Laboratory } \\
\text { Number }\end{array}$ & Site & Square & Spit & $\begin{array}{c}\text { Depth Below } \\
\text { Surface (cm) }\end{array}$ & $\begin{array}{c}\text { Sample } \\
\text { Material }\end{array}$ & D ${ }^{13}$ C & $\begin{array}{c}\text { Uncalibrated } \\
\text { Age (BP) }\end{array}$ & $\begin{array}{c}\text { Calibrated } \\
\text { Age (cal. BP) }\end{array}$ \\
\hline Wk-21215 & LP4 & NA & Surface & 0 & D. deltoides & NA & $813 \pm 36$ & $491-271$ \\
\hline ANU 6614 & LP4 & AK14 & 4 & 20 & Charcoal & $-29 \pm 3$ & $235 \pm 45$ & $321-$ modern \\
\hline ANU 6616 & LP4 & AA10 & 3 & 3 & D. deltoides & $-22 \pm 3$ & $1345 \pm 45$ & $947-673$ \\
\hline Wk-21218 & LP9 & NA & Surface & 0 & D. deltoides & NA & $1865 \pm 36$ & $1501-1227$ \\
\hline ANU 6619 & LP9 & AD & 1 & 5 & Charcoal & $-26 \pm 3$ & Modern & Modern \\
\hline ANU 6620 & LP9 & AD & 4 & 20 & Charcoal & $-23 \pm 3$ & $1825 \pm 40$ & $1816-1569$ \\
\hline ANU 6621 & LP9 & AD & 8 & 40 & Charcoal & $-29 \pm 2$ & $2100 \pm 40$ & $2121-1897$ \\
\hline ANU 6623 & LP9 & AY12 & 2 & 10 & Charcoal & $-20 \pm 3$ & $250 \pm 45$ & $439-$ modern \\
\hline ANU 6625 & LP9 & AY12 & 24 & 140 & Charcoal & $-21 \pm 3$ & $1840 \pm 40$ & $1822-1570$ \\
\hline ANU 6617 & LP9 & Y & 5 & 25 & Charcoal & $-24 \pm 3$ & $2175 \pm 45$ & $2306-1951$ \\
\hline ANU 6618 & LP9 & Y & 10 & 50 & Charcoal & $-26 \pm 4$ & $2340 \pm 55$ & $2455-2134$ \\
\hline ANU 3113 & LP11 & NA & Surface & 0 & D. deltoides & NA & $1385 \pm 40$ & $993-700$ \\
\hline ANU 6629 & LP11 & A & 4 & 20 & Charcoal & $-23 \pm 2$ & $380 \pm 40$ & $490-318$ \\
\hline ANU 6630 & LP11 & A & 11 & 55 & Charcoal & $-20 \pm 3$ & $995 \pm 50$ & $995-748$ \\
\hline ANU 6632 & LP11 & B & 3 & 15 & D. deltoides & NA & $1335 \pm 40$ & $930-671$ \\
\hline ANU 6633 & LP11 & C & 5 & 25 & Charcoal & $-23 \pm 3$ & $405 \pm 45$ & $499-322$ \\
\hline ANU 6631 & LP11 & C & 11 & 55 & Charcoal & $-22 \pm 4$ & $1780 \pm 50$ & $1810-1525$ \\
\hline ANU 2637 & LP16 & NA & Surface & 0 & D. deltoides & NA & $680 \pm 40$ & $415-$ modern \\
\hline ANU 2638 & LP16 & NA & Surface & 0 & Charcoal & NA & $870 \pm 40$ & $895-672$ \\
\hline ANU 6626 & LP16 & A8 & 9 & 45 & Charcoal & $-23 \pm 3$ & $735 \pm 50$ & $720-558$ \\
\hline ANU 6627 & LP16 & L8 & 5 & 25 & Charcoal & $-18 \pm 4$ & $350 \pm 50$ & $491-298$ \\
\hline
\end{tabular}

Table 1 Radiocarbon dates from excavated middens LP4, LP9, LP11 and LP16. 


\section{Site $L P 11$}

LP11 is a moderately dense shell midden measuring ca $40 \mathrm{~m}$ in length and $10 \mathrm{~m}$ in width, in which three $1 \mathrm{x} 1 \mathrm{~m}$ testpits (Squares A, B and C) were excavated and from which six radiocarbon dates were obtained. A sample collected during the 2007 survey produced an age estimate of 993-700 cal. BP, though this cannot be meaningfully related to those from the excavations as it was collected from an exposed section. The basal age estimate for Square A was 955-748 cal. BP, while an age estimate obtained from $20-25 \mathrm{~cm}$ bs (where cultural remains were densest) was $490-318 \mathrm{cal}$. BP. Owing to the lack of in situ charcoal in Square B, a shell sample associated with the lowest cultural material in this test-pit was dated, indicating initial site occupation at 930-671 cal. BP. The basal age for Square C was 1810-1525 cal. BP, with a sample from $25-30 \mathrm{~cm}$ bs in this same square returning an age estimate of 499-322 cal. BP.

\section{Site LP16}

LP16 is a low density shell midden covering ca $26 \times 20 \mathrm{~m}$, in which four 1 x $1 \mathrm{~m}$ test-pits were excavated (Squares A8, A20, L8 and L20). Four radiocarbon dates were obtained for LP16, along with basal dates for Squares A8 and L8, and a paired sample of charcoal and shell from the surface; no dates were obtained for Squares A20 and L20. The shell surface sample returned an age estimate of 415 cal. BP-modern (ANU 2637), while the paired charcoal surface sample returned an age estimate of 895-672 cal. BP. A basal sample from Square A8 returned an age estimate of 720-558 cal. BP, and in Square L8 an age of 491-298 cal. BP was obtained from Spit 5.

\section{Surface Samples from Other Sites}

Table 2 lists the dates obtained from the surface of a further eight sites recorded at Long Point in 2007. Of these, samples from sites LP3, LP7 and LP8 all returned modern age estimates, while the other five samples all dated to within the last 2000 years.

\section{Summary}

Based on the available radiocarbon age estimates, Long Point has an occupation history spanning ca 2500 years, with the oldest site, LP9, dating from $2455 \mathrm{cal}$. BP. The three other excavated middens in the locale indicate occupation younger than 2000 years BP:

- LP11 was deposited over a ca 1500 year period commencing 1810-1525 cal. BP;

- LP4 accumulated over a ca 950 year period commencing 947-673 cal. BP; and,
- LP16 accumulated over a ca 700 year period commencing 895-672 cal. BP.

With the exception of site LP11, which appears not to have been occupied after 500-300 cal. BP, all of the Long Point sites suggest continual use from ca 2000 cal. BP until relatively recently, providing empirical evidence supporting Ngarrindjeri assertions for their longevity and continued occupation in the region (Ngarrindjeri Tendi et al. 2007).

The surface dates obtained from the other eight shell matrix sites recorded in 2008 but not excavated also demonstrate occupation within the last 2000 years. As these age estimates are based on near-surface samples only, it is possible that initial occupation of these sites is older, though given the excavation results this is considered unlikely.

The discrepancy noted between the shellfish and charcoal dates is thought to be associated with shellfish absorbing old carbon from the limestone landscape, resulting in a significantly older age. Based on the paired shellfish and charcoal samples from LP16 (ANU 2367 and 2368, respectively), this discrepancy is estimated to be ca 500 years. All shell samples are considered likely to be affected by this phenomenon. While it is not discussed further here, analysis into an appropriate reservoir correction factor for shellfish from this region is recommended, though it was beyond the scope of this project.

Intrasite variability in occupation is also evident, though not unexpected, as the four excavated middens range in size from ca $400 \mathrm{~m}^{2}$ (LP11) to $15,000 \mathrm{~m}^{2}$ (LP9). One such example is LP11, where Square C indicates occupation commencing ca 900 years earlier than Square A (Table 1). Site LP9 is similar, with basal samples for Square $Y$ (at $50 \mathrm{~cm} \mathrm{bs}$ ) and Square AD (at $40 \mathrm{~cm}$ bs) returning age estimates of 2455-2134 cal. BP and 2121-1897 cal. BP, respectively, while Square AY12 (at $140 \mathrm{~cm}$ bs) dated to $1822-1570$ cal. BP (Table 1). Square AY12 is situated on a distinct mounded feature within the site (ca $1 \mathrm{~m}$ high) and its younger basal age indicates that the establishment of the mound occurred at a later date than use of the areas where Squares AD and $\mathrm{Y}$ were situated.

Despite the extensive excavation and dating programme at Long Point, no sites were located which were older than 2500 cal. BP. The late Holocene occupation of Long Point indirectly lends support, albeit in the form of an absence of evidence (which is not without issue), for Luebbers' hypothesis that, prior to $2000 \mathrm{BP}$, population densities in the Coorong were lower and marine resources were not as intensively exploited. Based on the results from the LP9 site, the commencement time for Luebbers' proposed intensive settlement phase could

\begin{tabular}{|c|c|c|c|c|c|}
\hline $\begin{array}{l}\text { Laboratory } \\
\text { Number }\end{array}$ & Site & Sample Material & $S^{13} \mathrm{C}$ & $\begin{array}{c}\text { Uncalibrated Age } \\
\text { (years BP) }\end{array}$ & $\begin{array}{l}\text { Calibrated Age } \\
\text { (cal. BP) }(95 \%)\end{array}$ \\
\hline Wk-21213 & LP1 & D. deltoides & $0.8 \pm 0.2$ & $2130 \pm 36$ & $1810-1474$ \\
\hline Wk-21214 & LP3 & D. deltoides & $0.4 \pm 0.2$ & $539 \pm 35$ & 237-modern \\
\hline Wk-21216 & LP7 & D. deltoides & $0.8 \pm 0.2$ & $617 \pm 34$ & 282-modern \\
\hline Wk-21217 & LP8 & D. deltoides & $0.6 \pm 0.2$ & $610 \pm 35$ & 276-modern \\
\hline ANU 3314 & LP10 & D. deltoides & $-5.2 \pm 2.7$ & $1120 \pm 35$ & $719-513$ \\
\hline ANU 2717 & LP13 & D. deltoides & $-3.8 \pm 2.1$ & $900 \pm 30$ & $543-309$ \\
\hline ANU 2714 & LP14 & D. deltoides & $-1.1 \pm 3.1$ & $1525 \pm 40$ & $1172-860$ \\
\hline ANU 2639 & LP15 & D. deltoides & $-2.3 \pm 2.0$ & $1600 \pm 35$ & 1230-938 \\
\hline
\end{tabular}

Table 2 Radiocarbon dates from surface collections. 
be refined to begin 500 years earlier than initially posited. The significance of the dated evidence for a change in this date is being prepared for publication elsewhere.

Significant archaeological changes occurred across much of Australia during the mid- to late Holocene. For example, in New South Wales, over half of all sites dated fall within the last 2000 years (Attenbrow 1999). Similar changes have been recorded further north, with Ulm (2006b) documenting distinct phases of occupation throughout the Holocene, akin in timing and nature to those of Luebbers. However, these patterns are not universal, as in both Victoria and some parts of Queensland there is a more even distribution of dated sites throughout the Holocene (e.g. Barker 1991; Bird and Frankel 1991; Faulkner 2009; O’Connor 1999). Developing local models of occupation independently from broader continental models is an essential component to ensuring that local variability and complexity are not lost on a broader scale (Frankel 1995; Ulm 2006b, 2013). Further analysis and radiocarbon dating of other deposits in coastal parts of Ngarrindjeri ruwe, and further afield in adjacent coastal areas, would assist in determining if this chronology is replicated along the coast, and thus assist in refining our understanding of occupation of the Coorong during the Holocene.

\section{Acknowledgements}

This paper is dedicated to the memories of Ngarrindjeri Elders, Uncles George Trevorrow, Tom Trevorrow and Matt Rigney, who fought so strongly for the Ngarrindjeri people and who recognised the potential of archaeology to support their heritage aspirations. To Alice Gorman, Kelly Wiltshire and Morgan Disspain, along with all the Flinders University students and the Ngarrindjeri Caring for Country rangers who participated in the Long Point field-school, thank you for all of your hard work and commitment. Thanks to our colleagues Jordan Ralph, Claire Ratican and Alice Gorman, who participated in a writing retreat hosted by Wallis Heritage Consulting during which this paper was crafted.

\section{Online Supplementary Material}

- Stratigraphic sections for each excavation square $(n=10)$.

- Site plans for four excavated sites and one surface concentration of shell.

\section{References}

Angas, G.F. 1847a Savage Life and Scenes in Austalia and New Zealand: Being an Artist's Impressions of Countries and People at the Antipodes. London: Smith Elder and Co.

Angas, G.F. 1847b South Austalia Illustrated. London: Thomas McLean.

Attenbrow, V. 1999 Archaeological research in coastal southeastern Australia: A review. In J. Hall and I. McNiven (eds), Australian Coastal Archaeology, pp.195210. Research Papers in Archaeology and Natural History 31. Canberra: ANH Publications, The Australian National University.

Baric, D. 2006 Unravelling Gender Constructs in Archaeology: Ngarrindjeri Archaeology, Fibre Culture and Masculinist Constructions. Unpublished BArch(Hons) thesis, Department of Archaeology, Flinders University, Adelaide. Barker, B.C. 1991 Nara Inlet 1: Coastal resource use and the Holocene marine transgression in the Whitsunday Islands, central Queensland. Archaeology in Oceania 26:102-109.

Barker, B.C. 2004 The Sea People: Late Holocene Maritime Specialisation in the Whitsunday Islands, Central Queensland. Terra Australis 20. Canberra: Pandanus Books, The Australian National University.

Barnett, E. 1995 Distinguishing natural and anthropogenic influences: A case study of Lake Alexandrina. South Australian Geographical Journal 94:36-49.

Beaton, J.M. 1985 Evidence for a coastal occupation time-lag at Princess Charlotte Bay (north Queensland) and implications for coastal colonisation and population growth theories for Aboriginal Australia. Archaeology in Oceania 20(1):1-20.

Beveridge, P. 1882 of the Aborigines inhabiting the great lacustrine and riverine depression of the lower Murray, lower Murrumbidgee, lower Lachlan and lower Darling. In Royal Society of New South Wales (ed.), Aboriginal Australians, pp.19-74. Sydney: Royal Society of New South Wales.

Bird, C.F.M. and D. Frankel 1991 Chronology and explanation in western Victoria and southeast South Australia. Archaeology in Oceania 26(1):1-16.

Bowdler, S. 1981 Hunters in the highlands: Aboriginal adaptations in the eastern Australian uplands. Archaeology in Oceania 16(2):99-111.

Bowdler, S. 1983 Sieving seashells: Midden analysis in Australian archaeology. In G. Connah (ed.), Australian Field Archaeology: A Guide to Techniques, pp.135-144. Canberra: Australian Institute of Aboriginal Studies.

Bowdler, S. 2006 Mollusks and other shells. In J. Balme and A. Paterson (eds), Archaeology in Practice: A Student Guide to Archaeological Analysis, pp.316337. Carlton: Blackwell Publishing.

Brock, F., T. Higham, P. Ditchfield and C.B. Ramsey 2010 Current pretreatment methods for AMS radiocarbon dating at the Oxford Radiocarbon Accelerator Unit (ORAU). Radiocarbon 52(1):103-112.

Campbell, T.D. 1934 Notes on the Aborigines of the southeast of Australia: Part I. Transactions of the Royal Society of South Australia 58:22-33.

Campbell, T.D. 1939 Notes on the Aborigines of the southeast of Australia: Part II. Transactions of the Royal Society of South Australia 63:27-35.

Campbell, T.D. 1947 Joint South Australia-Victoria Expedition to the lower southeast of Australia. Records of the South Australian Museum 8:445-501.

David, B. 2002 Landscapes, Rock Art and the Dreaming: An Archaeology of Preunderstanding. London: Leicester University Press

Fallon, S.J., L.K. Fifield and J.M. Chappell 2010 The next chapter in radiocarbon dating at The Australian National University: Status report on the single stage AMS. Nuclear Instruments and Methods in Physics Research Section B: Beam Interactions with Materials and Atoms 268:898-901.

Faulkner, P. 2009 Focused, intense and long-term evidence for grandular ark (Anadara granosa) exploitation from late Holocene shell mounds of Blue Mud Bay, northern Australia. Journal of Archaeological Science 36:821-834.

Flood, J. 1999 Archaeology of the Dreamtime: The Story of Prehistoric Australia and Its People ( $3^{\text {rd }}$ ed.). Sydney: Angas and Robertson.

Fluin, J., P. Gell, D. Haynes, J. Tibby and G. Hancock 2007 Palaeolimnological evidence for the independent evolution of neighbouring terminal lakes, the Murray Darling Basin, Australia. Hydrobiologica 591:117-134.

Frankel, D. 1995 The Australian transition: Real and perceived boundaries. Antiquity 69:649-655.

Harvey, N. 1981 Coastal geomorphology of southeast South Australia. Taminga Journal of the Teachers Association of South Australia 18(3):1-15.

Hiscock, P. 1994 Technological responses to risk in Holocene Australia. Journal of World Prehistory 8:267-292.

Hiscock, P. 2006 Blunt and to the point: Changing technological strategies in Holocene Australia. In I. Lilley (ed.), Archaeology in Oceania, Australia and the Pacific Islands, pp.69-95. Oxford: Blackwell.

Hughen, K.A., M.G.L. Baillie, E. Bard, A. Bayliss, J.W. Beck, C.J.H. Bertrand, P.G. Blackwell, C.E. Buck, G.S. Burr, K.B. Cutler, P.E. Damon, R. Edwards, R.G. Fairbanks, M. Friedrich, T.P. Guilderson, B. Kromer, F.G. McCormac, S.W. Manning, C. Bronk Ramsey, P.J. Reimer, R.W. Reimer, S. Remmele, J.R. Southon, M. Stuiver, S. Talamo, F.W. Taylor, J. Van der Plicht and C.E. Weyhenmeyer 
2004 Marine04 Marine radiocarbon age calibration, 26-0 ky BP. Radiocarbon 46:1059-1086.

Hughes, P.J. and R.J. Lampert 1982 Prehistoric population change in southern coastal New South Wales. In S. Bowdler (ed.), Coastal Archaeology in Eastern Australia: Proceedings of the 1980 Valla Conference on Australian Prehistory, pp.16-28. Canberra: Australian National University Press.

Krull, E., D. Haynes, S. Lamontagne, P. Gell, D. McKirdy, G. Hancock, J. McGowen and R. Smernik 2009 Changes in the chemistry of sedimentary organic matter within the Coorong over space and time. Biogeochemistry 92:9-25.

Lourandos, H. 1980 Change or stability? Hydraulics, hunter-gatherers and populations in temperate Australia. World Archaeology 11(3):245-264.

Lourandos, H. 1983 Intensification: A late Pleistocene-Holocene archaeological sequence from southwestern Victoria. Archaeology in Oceania 18:81-94.

Lourandos, H. 1985 Intensification and Australian prehistory. In T.D. Price and J.A. Brown (eds), Prehistoric Hunter-Gatherers: The Emergence of Cultural Complexity, pp.385-423. Orlando: Academic Press.

Lourandos, H. 1988 Palaeopolitics: Resource intensification in Aboriginal Australia and Papua New Guinea. In T. Ingold, D. Riches and J. Woodburn (eds), Hunters and Gatherers 1: History, Evolution and Social Change, pp.148-160. New York: Berg.

Luebbers, R.A. 1978 Meals and Menus: A Study of Change in Prehistoric Coastal Settlement in South Australia. Unpublished PhD thesis, Department of Archaeology and Anthropology, The Faculties, The Australian National University, Canberra.

Luebbers, R.A. 1981 The Coorong Report: An Archaeological Survey of the Southern Younghusband Peninsula. Unpublished report prepared for the South Australian Department for the Environment and Planning.

Luebbers, R.A. 1982 The Coorong Report: An Archaeological Survey of the Northern Coorong. Unpublished report prepared for the South Australian Department of Environment and Planning.

McCormac, F.G., A.G. Hogg, P.G. Blackwell, C.E. Buck, T.F.G. Higham and P.J. Reimer 2004 SHCal04 Southern Hemisphere Calibration 0-1000 cal. BP. Radiocarbon 46:1087-1092.

Meara, T.A. 2007 Politics of the Dead: A Comparative Analysis of Legislative Options for the Reburial of Repatriated Indigenous Human Remains in Southeastern Australia. Unpublished BArch(Hons) thesis, Department of Archaeology, Flinders University, Adelaide.

Mulvaney, D.J. 1969 The Prehistory of Australia. London: Thames and Hudson.

Ngarrindjeri Tendi, Ngarrindjeri Heritage Committee and Ngarrindjeri Native Title Committee 2007 Ngarrindjeri Nation Sea Country Plan: Caring for Ngarrindjeri Country and Culture. Meningie: Ngarrindjeri Land and Progress Association.

Niland, K. 2007 Understanding Old People's Burial Practices in the Kurangk, South Australia: A Case Study from Hack's Point. Unpublished BArch(Hons) thesis, Department of Archaeology, Flinders University, Adelaide.

O'Connor, S. 1999 30,000 Years of Aboriginal Occupation: Kimberley, Western Australia. Terra Australis 14. Canberra: Department of Archaeology and Natural History, The Australian National University.
Rowland, M.J. 1983 Aborigines and environment in Holocene Australia: Changing paradigms. Australian Aboriginal Studies 1983(2):62-77.

Rowland, M.J. 1989 Population increase, intensification or a result of preservation? Explaining site distribution patterns on the coast of Queensland. Australian Aboriginal Studies 1989(2):32-41.

Rowland, M.J. 1999 Holocene environmental variability: Have its impacts been underestimated in Australian prehistory? The Artefact 22:11-48.

Santos, G.M., J.R. Southon, K.C. Druffel-Rodriguez, S. Griffin and M. Mazon 2004 Magnesium perchlorate as an alternative water trap in AMS graphite sample preparation: A report on sample preparation at the KCCAMS Facility at the University of California, Irvine. Radiocarbon 46(1):165-173.

St George, C. 2009 Investigating Subsistence Strategies in Ngarrindjeri Ruwe through a Study of Mid- to Late Holocene Aged Shell Middens, Long Point, South Australia. Unpublished BArch(Hons) thesis, Department of Archaeology, Flinders University, Adelaide.

Stuiver, M. and H.A. Polach 1977 Discussion reporting of 14C data. Radiocarbon 19(3):355-363.

Taplin, G. 1874 The Narrinyeri. In J.D. Woods (ed.), The Native Tribes of South Australia, pp.1-9. Adelaide: E.S. Wiggs.

Tindale, N. 1974 Aboriginal Tribes of Australia. Canberra: Australian Institute of Aboriginal Studies.

Ulm, S. 2006a Austalian marine reservoir effects: A guide to Australian $\Delta \mathrm{R}$ values. Australian Archaeology 63:57-60.

Ulm, S. 2006b Coastal Themes: An Archaeology of the Southern Curtis Coast, Queensland. Terra Australis 24. Canberra: ANU E Press.

Ulm, S. 2013 'Complexity' and the Australian continential narrative: Themes in the archaeology of Holocene Australia. Quaternary International 285:182-192.

Wallis, L.A. 2007a Long Point Indigenous Cultural Heritage Survey: Initial Archaeological Results (Section 571). Unpublished report prepared for the Dapung Talkinjeri Aboriginal Corporation.

Wallis, L.A. 2007b Long Point Indigenous Cultural Heritage Survey: Summary of all Archaeological Results (Sections 571 and 572). Unpublished report prepared for the Dapung Talkinjeri Aboriginal Corporation and Ngarrindjeri Heritage Committee.

Wallis, L.A. and M. Disspain 2008 Archaeological Investigations of Midden Sites at Long Point, April 2008. Unpublished report prepared for the Dapung Talkinjeri Aboriginal Corporation, Ngarrindjeri Heritage Committee and Ngarrindjeri Regional Authority.

Wilson, C.J. 2005 Return of the Ngarrindjeri: Repatriating Old People Back to Country. Unpublished BArch(Hons) thesis, Department of Archaeology, Flinders University, Adelaide.

Wiltshire, K.D. 2005 Unfinished Business: The Lower Murray Lakes Archaeological Study within an Historical and Political Context. Unpublished BArch(Hons) thesis, Department of Archaeology, Flinders University, Adelaide.

Wiltshire, K.D. and L.A. Wallis 2008 A history of Aboriginal heritage protection legislation in South Australia. Journal of Environment Planning and Law 25(2):98-114. 